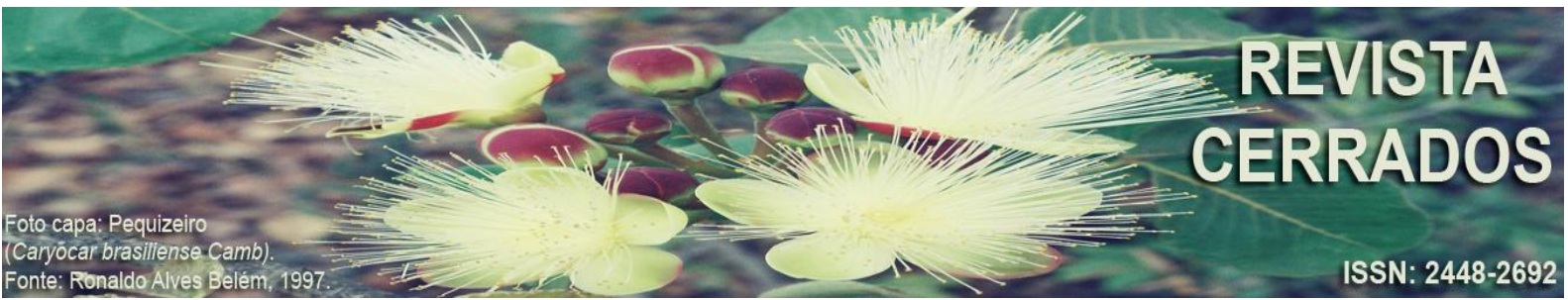

\title{
CONSTRUINDO SENTIDOS NAS LEITURAS DE IMAGENS: um estudo sobre os livros didáticos de Geografia
}

\section{BUILDING SENSES IN THE READING OF IMAGES: a study over the Geography schoolbooks}

\section{CONSTRUYENDO SENTIDOS EN LAS LECTURAS DE IMAGEN: Un estudio de los libros escolares de Geografía}

\author{
Juliano da Costa Machado Timmers \\ Universidade Federal do Rio Grande do Sul - UFRGS \\ E-mail: <00104728@ufrgs.br>. \\ Branda Eloá Weppo \\ Universidad de la Empresa - UDE Montevidéu/Uruguai \\ E-mail: <brandaweppo@live.com>.
}

\begin{abstract}
Resumo
O presente artigo traz uma análise sobre as capas de livros didáticos de Geografia do ensino básico. Tal análise busca refletir as possibilidades de leituras de sentido que podem ser mobilizadas pelos conteúdos de imagem das capas desse tipo de livro. Espera-se com essa perspectiva colaborar para com o desenvolvimento da educação visual de professores e alunos. A experiência espacial atual é exposta como sendo muito influenciada pela produção de imagens, o que reforça a importância do conhecimento sobre as formas de olhar. Reflexões sobre linguagem visual são desenvolvidas, considerando-se especialmente os estudos de Roland Barthes. Os instrumentos de interpretação visual desse autor são encaminhados junto às capas de livros didáticos de Geografia o que permite identificar os sentidos derivados dessas imagens, descrevendo abordagens geográficas e com elas a maior valorização da representação de grupos minoritários.
\end{abstract}

Palavras-chave: educação visual; livro didático; ensino de Geografia; semiótica.

\begin{abstract}
The paper brings an analysis over the cover of Geography schoolbooks. This analysis tries to reflect the possibilities of sense of reading which can be achieved by the image contents of the cover of these sort of book. We expect with such a perspective to develop the visual education to teachers and the students. The nowadays spatial experience is exposed as being very much
\end{abstract}


influenced by the image production, which reinforce the importance of knowledge over the ways of seeing. Reflections over the visual language are developed, specially, considering on it the Roland Barthes studies. The author's instruments of visual interpretation are applied over the cover of Geography Schoolbooks, what allow us to identify senses from the images, describing Geographic approaches and also a larger relevance for the representation of the minority groups.

Key-words: visual education; schoolbook; Geography teaching; semiotic.

\section{Resumen}

En este trabajo presenta un análisis de las portadas de los libros escolares de geografía de la escuela primaria. Este análisis busca reflejar las posibilidades de lecturas de los sentidos que pueden ser movilizados por el contenido de las imágenes de las portadas de este tipo de libros. Esperamos con esta perspectiva contribuir al desarrollo de la formación visual de los profesores y estudiantes. La experiencia espacial actual se expone como siendo fuertemente influenciada por la producción de imágenes, lo que refuerza la importancia de los conocimientos sobre la forma de mirar. Reflexiones sobre el lenguaje visual se desarrollan, especialmente teniendo en cuenta los estudios de Roland Barthes. Los instrumentos de interpretación visual de este autor se encaminan en la análisis de las portadas de los libros escolares de geografía lo que permite identificar los significados derivados de sus imágenes, describiendo enfoques geográficos y una mayor importancia de la representación de los grupos minoritarios.

Palabras clave: educación visual; libro escolar; enseñanza de la geografía; semiótica.

\section{INTRODUÇÃO}

O presente artigo se desenvolve a partir de uma proposta de análise sobre as capas de livros didáticos de Geografia dos anos finais do ensino fundamental. Essa análise visa delinear que leituras de sentido podem vir a ser mobilizadas pelo contato inicial com suas capas. Se objetiva, portanto, refletir sobre as leituras possíveis, mais especificamente sobre como elas podem ter influência sobre a afirmação de olhares e perspectivas geográficas tanto de professores como de alunos.

Os livros didáticos de geografia tiveram enorme importância na afirmação de uma determinada leitura de nação e hoje apesar de apresentarem propostas de ensino mais diversificadas, o seu papel não é menos importante na definição sobre como nos vemos, sobre o que valorizamos espacialmente. Não é à toa que eles têm uma grande produção e movimentam grande parte do mercado editorial brasileiro. Desse modo sua elaboração envolve uma grande equipe de profissionais, que incluem diagramadores, designers e 
especialistas em geografia, os quais são responsáveis principalmente pelo texto e pela indicação de recursos visuais como fotos, gráficos, mapas e ilustrações (SENE, 2013). Toda confecção de livro didático é pensada de modo a criar uma estrutura de sentidos que dialoguem de forma coerente com a proposta de ensino de geografia expressa pelos autores, sendo o projeto gráfico editorial um dos critérios apresentados pelos editais do Ministério da Educação (MEC) de modo fornecer a aprovação do órgão às Coleções produzidas pelas editoras.

A capa, assim como todo projeto gráfico, é um importante elemento de comunicação dos conteúdos geográficos, daí sua importância. Ela também tem como função atrair o olhar, se configurando em um elemento estratégico, pois mesmo depois de aprovada pelo MEC, as Coleções precisam ser selecionadas nas escolas pelos professores, sendo a capa o primeiro elemento de contato do público leitor com o livro.

Dividimos o texto que se segue em uma contextualização sobre a importância das imagens e suas relações com as nossas formas de interação com o espaço geográfico contemporâneo. Posteriormente apresentamos os recursos de semiótica e dos estudos culturais que empregaremos junto à análise de nosso objeto de estudos. Busca-se verificar também como e com quais matrizes de pensamento da geografia as interpretações de sentido das capas estabelecem diálogos. Nesse contexto serão apresentadas interpretações de capas de livros didáticos de geografia, brevemente discutidas, para, em seguida, aplicarem-se os instrumentos de análise apresentados sobre as capas da coleção "Expedições Geográficas".

\section{Livros no contexto de sociedades imagéticas}

Sabe-se que a cultura livresca sempre apresentou muitas dificuldades de desenvolvimento no Brasil, apesar de vir crescendo o número de leitores no país. Aspectos como o custo do livro, se conjugam aos diversos condicionantes que distanciam um maior número de brasileiros da leitura de livros. Por outro lado o brasileiro é bastante ativo em redes sociais onde lê, escreve, acessa e compartilha conteúdos visuais - vídeos e fotos. Seu modo de acesso são os dispositivos eletrônicos móveis, celulares e tablets. Desde muito cedo as crianças costumam fazer uso desses aparelhos, o que pode ser positivo, pois aprender ler, de acordo com Barbosa (2010), envolve um processo que tem profundas relações imagéticas a começar pela identificação gráfica das letras. 
Vale ressaltar que o mundo globalizado não demanda daqueles que vivem nele a leitura apenas do texto escrito nos estilos diversos da literatura. A multiplicidade textual e a intertextualidade são evidentes no contexto em que os objetos se multiplicam por portarem dimensões informacionais como nos aponta Milton Santos (2012). Ocorre que o texto e a narrativa correlata são também visuais hoje. Visuais no sentido de comunicarem signos através de imagens sejam elas fotografias, desenhos, logos, enfim grafias diversas que se misturam ao texto escrito. O manual de instruções de um aparelho celular (Figura 1), por exemplo, pode evidenciar um pouco dessa relação de entrelaçamento entre texto visual e escrito. $\mathrm{O}$ fato é que em nenhum outro tempo se produziram tantas imagens.

\section{Figura 1 - Captura de tela do Manual de instruções do Iphone 7}

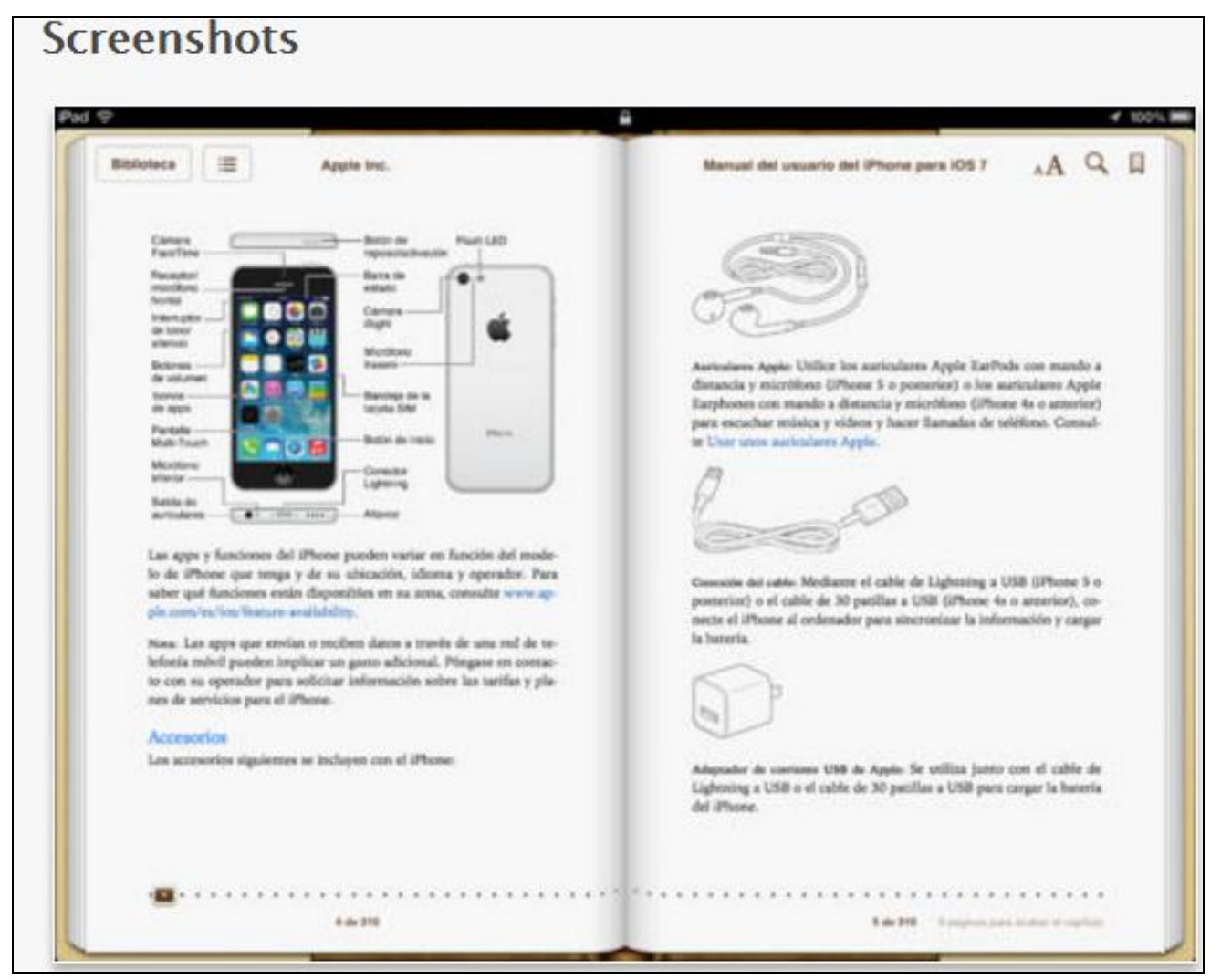

A imagem se faz cada vez mais presente no contexto espacial determinado pelo meio técnico-informacional.

\section{Fonte: <ItunesApple.com>}

Fala-se em uma cultura visual a se globalizar. A expansão desse tipo de cultura, balizada por instrumentos técnicos, desenvolve-se como um fenômeno relativamente novo na história e se manifesta como "reflexo da crise e sobrecarga de informação na vida diária e da necessidade de encontrar formas de investigação e respostas frente às novas realidades 
(virtuais)" (HERNANDEZ, 2005, p. 21). Não vivemos em uma realidade virtual propriamente dita, contudo, seguramente vivemos em um cotidiano marcado por crescente virtualização. A produção e difusão vertiginosamente grande de imagens digitais têm conferido uma marca que distingue a espacialidade em que nos inserimos, o que caracteriza o fenômeno das visualidades hoje como absolutamente geográfico. As relações entre as formas de ver, suas tecnologias e a produção espacial possuem laços bastante estreitos. Exemplo disso é o fato de termos realçado nosso hábito de interagir com paisagens, fotografando-as, acrescentando-lhes quase que instantaneamente efeitos de cores, filtros, e as compartilhando em nossa rede de amigos de maneira a torná-las presentes virtualmente em nossa experiência espacial.

$\mathrm{O}$ texto escrito se associa às linguagens visuais e essas linguagens conjugadas têm mediado nossa relação com o espaço. Nesse contexto crescentemente imagético, é importante tratar de visualidades, isto é, das formas como vemos. Pensar as visualidades passa por discutir sua produção o que nos leva tanto a interpretar os sentidos que as imagens podem manifestar, bem como analisar o jogo que determina a leitura desses sentidos. Esse pode ser um caminho para tornar mais objetivo o processo, para compreendê-lo melhor e usá-lo como instrumento de análise que é o que nos interessa nesse estudo.

\section{Formas de análise da linguagem visual e as concepções de Geografia}

Antes de passarmos diretamente à análise das capas dos livros, nos dediquemos antes a pensar um pouco sobre o caminho analítico que se pretende percorrer. Busca-se desenvolver leituras sobre signos que nos levam a utilização de recursos oriundos do estudo dos signos, a semiótica. A abordagem semiótica que utilizaremos aqui passa pelos estudos do lituano Algirdas Julius Greimas, o qual foi um grande desenvolvedor de uma teoria semiótica oriunda da literatura, em especial da poesia. Na sua busca por verificar a gramática dos sentidos da poesia, esse autor acabara por delinear um campo de estudos, o qual adquirira com o tempo maior autonomia em relação à linguística, área do conhecimento que envolvia os estudos de semiótica então. A causa dessa derivação se deu, pois a abordagem reinante quanto aos estudos do signo não contemplava com o devido rigor as especificidades do signo poético, o qual apresentava peculiaridades que por vezes iam além da lógica aplicada a outros textos literários. De modo que: 
Os signos, definidos, de acordo com a tradição saussureana, pela reunião de um significante e de um significado, podem ter dimensões desiguais: uma palavra, uma frase, são signos, mas também um discurso, na medida em que este se manifesta como uma unidade discreta. Numa primeira abordagem, o discurso poético pode ser considerado como um signo complexo (GREIMAS, 1975, p. 16).

Se o texto delimitado é o signo poético manifesto, o estudo das articulações de significado que nascem da sua leitura acabou por criar a semiótica de Greimas. Não por acaso que partir do contexto vivido por esse autor que a poética e o desenvolvimento da análise de seus signos se ampliam de modo a envolver linguagens que não se restringem apenas ao texto poético literário, mas também a outras linguagens que possuíam redes de sentido complexas e similares a exemplo das artes visuais com o estudo das imagens.

No que se refere à semiótica das imagens consideramos Roland Barthes. Esse autor, cujos estudos se voltaram à fotografia e suas aplicações em publicidade, possui um papel relevante para pensarmos as relações possíveis e a conciliação entre imagem e texto. Os livros didáticos de geografia em especial, objeto de estudo desse artigo, possuem uma linguagem muito próxima ao jornalismo, que por sua vez muito dialogam em diversos aspectos com a publicidade estudada por Barthes. Muitos livros didáticos inclusive veiculam charges e matérias de jornal dentro dos seus capítulos. As fotos dos livros são obtidas de grandes bancos de agências jornalísticas internacionais (SENE, 2013). Por essa razão é que pensamos não haver prejuízo em aplicar uma metodologia de análise da semiótica da mensagem publicitária de Barthes em relação às capas dos livros didáticos de Geografia.

O modelo desenvolvido por Barthes (1990) é bastante simples, considera a análise de três mensagens, a linguística (verbal), a mensagem conotada (simbólica) e a mensagem denotada (icônica). A função da linguagem verbal é auxiliar a imagem. Ela ancora mensagens e se define como etapas às mensagens. A mensagem conotada se liga aos aspectos simbólicos incorporados às imagens, os quais dialogam com o texto escrito. Já a mensagem denotada se liga ao objeto real que a imagem apresenta em contraposição àquilo que ela conota a partir dele. Esse conjunto de mensagens dará corpo àquilo que o autor chamou de retórica da imagem.

A abordagem semiótica, de estudo dos sistemas de significação, portanto, compõe um primeiro plano de análise que buscamos aplicar às capas dos livros didáticos de modo que com tal abordagem possamos verificar as construções de sentido junto ao público a quem se dirigem, a saber, fundamentalmente professores e alunos. Delineado o percurso dos sentidos 
que as capas nos convidam a fazer, partimos para um segundo plano analítico que se associa aos estudos culturais dirigidos a reflexões sobre imagens.

Os estudos culturais se caracterizam por estudos que vieram renovar as abordagens acerca da cultura (COSTA et al, 2003). Seu desenvolvimento remonta o póssegunda guerra quando o conceito de cultura é reinterpretado indo além de uma perspectiva elitista. Com esses estudos o termo "cultura" passa a ser usado no plural e adjetivado, rompendo com um paradigma restrito sobre o mesmo. Além disso, a cultura popular não é mais abordada como inferior, por oposição a "Cultura", portanto, torna-se relevante para ser estudada como manifestação estética genuína, bem como de valores de parte de específicos grupos sociais.

Em relação à análise de imagens da publicidade, do jornalismo e outros meios, que podem incluir os livros didáticos inclusive, os estudos culturais são utilizados principalmente para expor macronarrativas que nos influenciam, isto é, esses estudos virão identificar como os grandes empreendimentos que mobilizam a cultura de massas - por exemplo, as corporações de mídia, os estúdios de cinema e também o Estado com os livros didáticos de distribuição nacional -, de modo a atuar de forma sistêmica e sutil produzindo visualidades, conformam gostos e preferências estéticas. Eles desse modo se constituem em agentes hegemônicos para valoração estética ainda que hoje a rede mundial de computadores imprima uma tendência à horizontalidade em relação à produção e consumo de imagens.

Acaso (2006), em um texto tão simples quanto revelador aponta que o funcionamento dos grandes veículos de mídia acaba por gerar no imaginário coletivo verdadeiros "terrores visuais" formados a partir da contraposição de tudo aquilo que é eleito visualmente como bom, belo e saudável por esses agentes. Segundo a autora há três categorias para se classificarem as imagens que buscamos evitar, os quais se descrevem por "terrores do corpo", como, por exemplo, não ser esbelto, "terrores de classe" o que inclui não se ter condições para viajar a lazer e "terrores culturais" o que se determina por não ser branco, não ser homem e também não ser ocidental. Aqueles que não se enquadram dentro dos perfis ideais de corpo, classe e cultura manifestam-se nas micronarrativas, isto é, na cultura de grupos marginalizados no âmbito do modo de produção globalizado. Espacialmente os agentes dessas micronarrativas compõem paisagens numerosas, de favelas, passando por aldeias, a periferias urbanas, as quais a despeito de serem numerosas sobre os territórios do planeta, formam espaços que assim acabam caracterizados como rejeitáveis e opacos, 
invisíveis às lentes e aos olhares dominantes. É possível ainda estabelecer um diálogo entre as macro e micronarrativas para os estudos visuais que se busca aqui implementar e as diferentes concepções de geografia. No âmbito do ensino de geografia podemos agrupar as três principais perspectivas sobre a ciência do espaço que remontam a Geografia Tradicional, a Geografia Crítica e a Geografia Cultural.

Por Geografia Tradicional se entende uma abordagem que se pretende mais técnica, mais ligada tanto a geografia física como aos instrumentos para esquadrinhar o espaço a exemplo da cartografia e do sensoriamento remoto. Vesentini (1992) destaca que o modelo tradicional se caracteriza pela abordagem do tipo "a terra e o homem". A Geografia Crítica talvez não tenha se diferenciado da tradicional no que se refere aos temas, porém são características dela o método relacional quanto as diferentes esferas do espaço - a cultura, a natureza, a política, entre outras. Também a caracterizam, a exposição das relações de classes e as contradições daí resultantes. Já a Geografia Cultural se destaca por valorizar o lugar, o local e os grupos humanos territorializados nessas espacialidades, bem como o estabelecimento de metodologias que contemplem a percepção do espaço a partir da esfera local.

De certa forma a geografia tradicional é praticamente onipresente nos livros didáticos produzidos até hoje, ainda que não se encontrem coleções nas escolas constituídas por uma abordagem estritamente técnica sobre o espaço. Logo os livros escolares hoje em sua maioria conjugam o viés técnico com elementos marcados pelas duas últimas vertentes geográficas apresentadas. Tanto a Geografia Crítica (Figura 2), como a Cultural (Figura 3), valorizam as micronarrativas.

As imagens apresentadas denotam formas diferentes de se olhar para uma mesma espacialidade do país nos livros didáticos. Podemos pensar que ambas nos remetem as espacialidades da região norte, sendo que a primeira centraliza o trabalhador madeireiro e a segunda coloca em seu foco um indígena em um momento de lazer, sorrindo enquanto olha para a tela. As duas capas têm paisagens verdes no seu entorno. A primeira ressalta o aspecto do drama social brasileiro, já a segunda evidencia um momento descontraído em um lugar remoto. 
TIMMERS, J. C. M.; WEPPO, B. E.

Construindo sentidos nas leituras de imagens: um estudo sobre os livros didáticos de geografia

Figura 2 - Capa do livro didático "Brasil: sociedade e espaço"

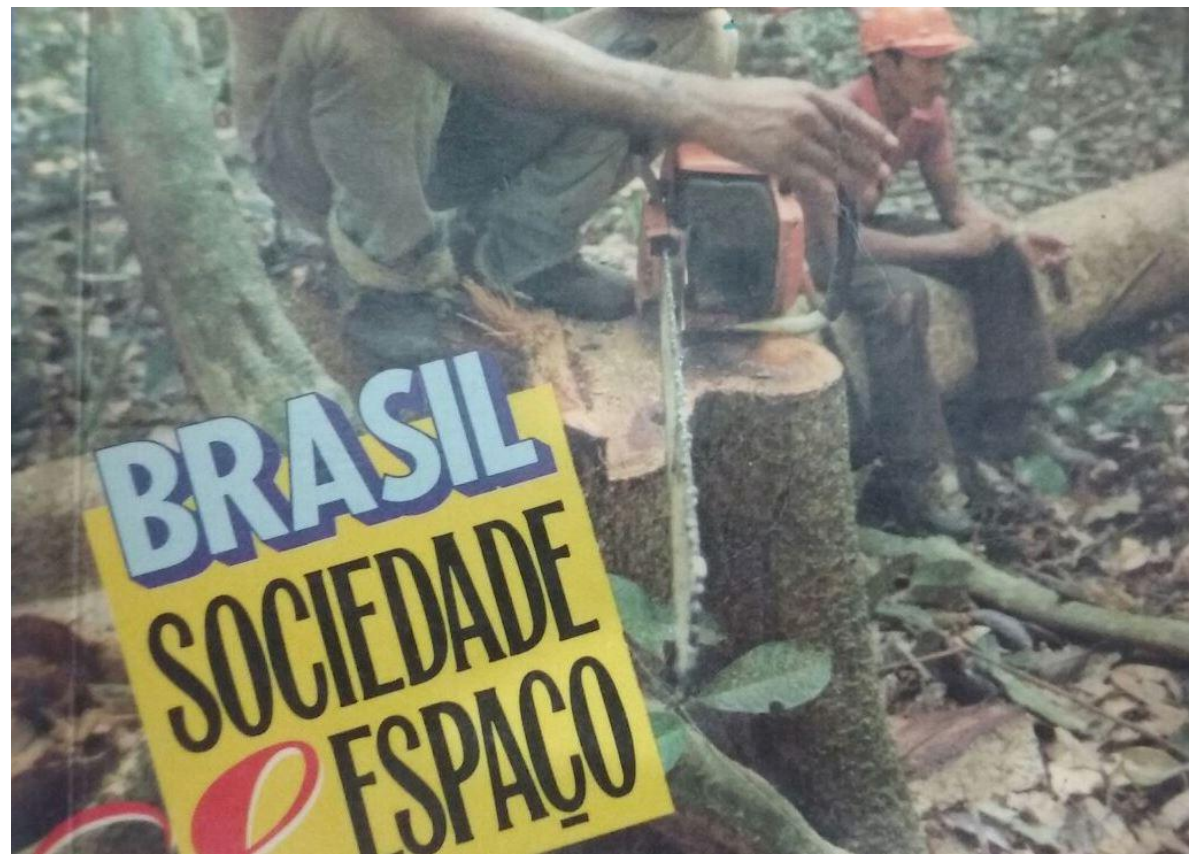

Esta capa de livro didático evidencia a relação entre "sociedade e espaço" sobre a foto de funcionários de uma madeireira nitidamente cansados e tem como função denotar um aspecto de desigualdade social caro às abordagens da Geografia Crítica. Fonte: VESENTINI, 1991. Foto: Branda EloáWeppo.

Figura 3 - Capa do livro didático "Geografia: homem e espaço"

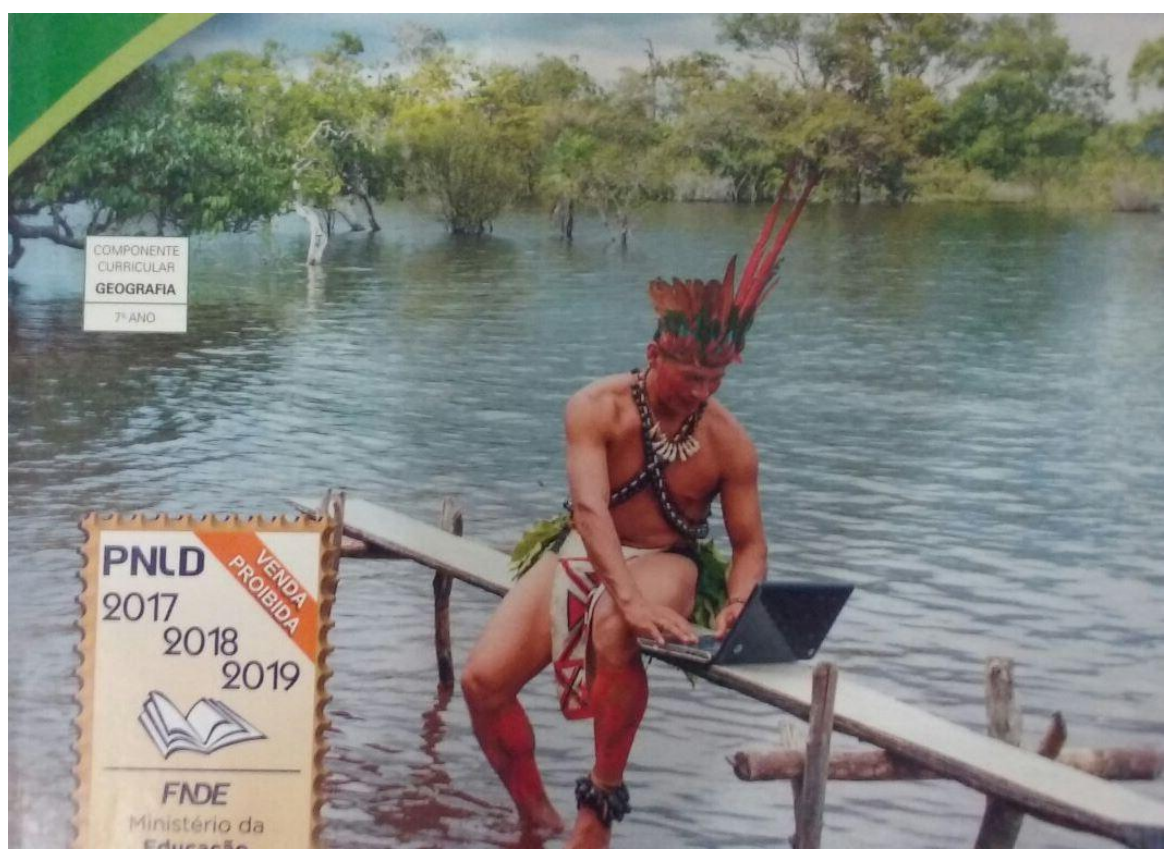

A fotografia desta capa centraliza um indígena brasileiro, o que se avalia pela indumentária, pelas cores do "layout" da capa e pelo conteúdo do livro didático. Apesar de parecer pouco verossímil, seja pelo forte caráter cênico da imagem, ou por colocar alguém manuseando um notebook dentro de uma várzea alagada, a 
imagem reforça a micronarrativa de um grupo social com pouca representatividade para as grandes mídias. Fonte: LUCCI, 2015. Foto: Branda Eloá Weppo.

Como observamos a partir dessas imagens, as capas de livros didáticos portam sentidos que se ancoram em marcadas concepções de Geografia mesmo que seus conteúdos não sejam homogêneos em relação à abordagem geográfica declarada por seus autores. Ainda que os livros didáticos das ciências sociais como a Geografia tenham servido em um passado nem tão distante a interesses estatais marcados, no sentido de forjar uma ideia nação pela definição de um tipo de imaginário, as capas desses livros didáticos hoje tendem a não revelar de maneira linear uma determinada abordagem geográfica ou um interesse marcado de agente específico. A análise mais elaborada sobre as capas, entretanto, pode identificar a partir da composição dos elementos de imagens qual concepção de geografia se valoriza mais no livro e de que forma ela caracteriza as pequenas narrativas como a dos grupos indígenas, das mulheres, dos homossexuais, afro-brasileiros e outros grupos que não costumam ter uma representação privilegiada no imaginário coletivo. Vale ressaltar que há diversas legislações contempladas nos editais do Programa Nacional do Livro Didático (PNDL), as quais definem que os livros reconhecidos pelo MEC devem considerar aspectos de uma formação cidadã como é o caso da lei 11.645/2008 relativa à obrigatoriedade do ensino da temática "História e Cultura Afro-Brasileira e Indígena”.

\section{As capas da coleção "Expedições Geográficas", suas leituras de sentido e os olhares geográficos que proporcionam}

Primeiramente vamos definir por que decidiu-se trabalhar com essa coleção. A principal razão para a escolha foi a praticidade. Esse conjunto de livros foi largamente utilizado por um dos autores desse artigo, que é professor de Geografia do Ensino Básico em uma escola municipal de ensino fundamental, Paul Harris, em São Leopoldo, cidade da Região Metropolitana de Porto Alegre/RS. Tal coleção foi enviada pela secretaria municipal de educação, sendo que essa não foi a primeira opção escolhida entre os livros apresentados aos professores de geografia da escola para o triênio que se iniciou em 2014.

Na prática de ensino do referido autor, o livro fora usado desde então, sobretudo, no que se refere ao emprego de fotos e gráficos principalmente. $\mathrm{O}$ texto é usado em atividades complementares como exercícios de fixação ou algumas recuperações. De qualquer forma não 
se quer aqui desenvolver uma análise que redunde em um juízo de valor do tipo "o livro é bom" ou "o livro é ruim". O que se busca fundamentalmente é evidenciar a importância da leitura visual que o professor pode desenvolver e com isso melhorar as aulas e propostas de ensino que contemplam imagens.

Comecemos nossa análise observando os elementos que juntos compõem a mensagem denotada, isto é, um conjunto de significantes que identifica elementos conhecidos, "reais". A coleção dos autores Melhem Adas e Sérgio Adas (2011) é composta por quatro livros (Figura 4) relativos aos quatro anos finais do ensino fundamental.

Figura 4 - Capas dos livros da coleção "Expedições Geográficas"

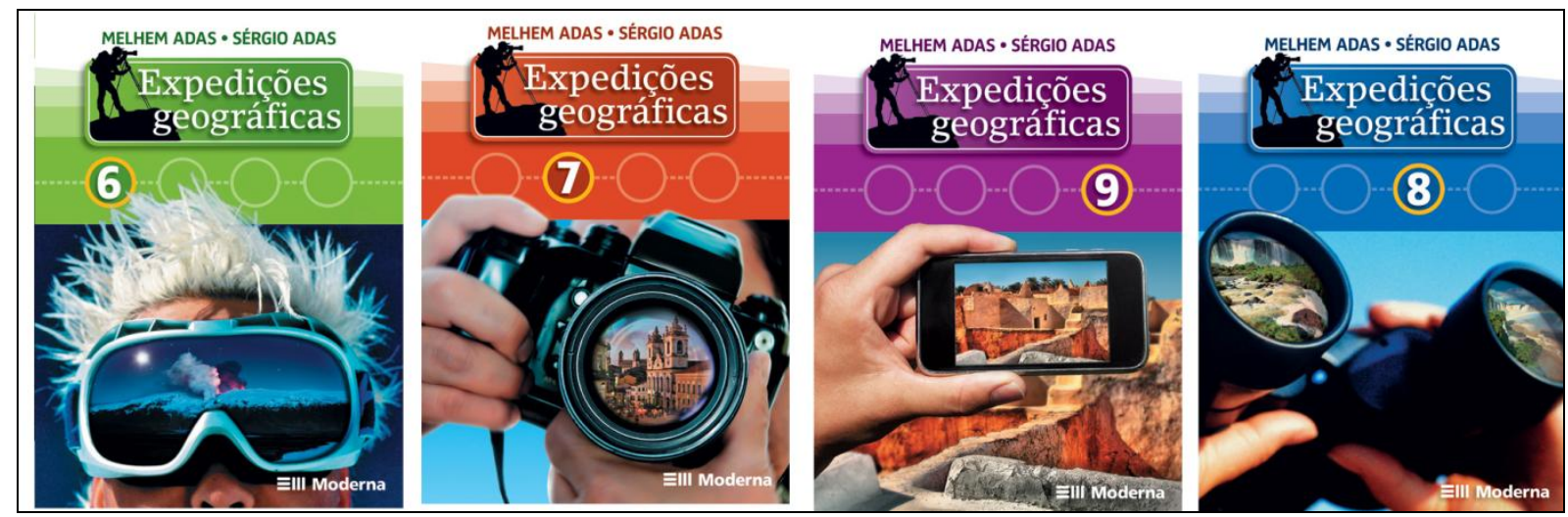

A coleção tem um padrão gráfico bastante homogêneo em suas capas e sua comunicação é eminentemente visual, isto é, há pouco texto. Fonte: Editora Moderna.

Observando as capas por um plano de expressão visual percebemos que elas são muito similares diferenciando-se apenas pela fotografia, elemento valorizado que envolve pouco mais da metade de toda a capa, e pelas cores de fundo em cada livro da coleção. É interessante notar que em todas as fotos o olho humano vê paisagens por um filtro que descreve uma máscara para neve, uma câmera fotográfica, um celular e um binóculo. Esses objetos nos remetem objetivamente a dimensão tecnológica a qual se evidencia como uma unanimidade no contexto das capas da coleção.

A parte que toca a mensagem textual é enxuta, porém possui uma função clara de ancoragem, isto é, privilegiar certas leituras. A coleção sugere que os leitores, isto é, os alunos juntos do seu "guia", no caso o professor, farão uma "expedição geográfica". Na apresentação do primeiro livro da série esse direcionamento é enfatizado na afirmação "ao percorrer e virar cada página deste livro, atento às orientações do professor, seremos companheiros de 
viagem!" (ADAS \& ADAS, 2011, p. 3). A análise do texto nas capas, portanto, identifica uma função bem específica que ratifica a ideia de passeio, tour, bem ao gosto do que têm sido algumas das apropriações da Geografia Cultural no ensino de geografia.

A mensagem simbólica que parece percorrer todas as capas se refere às imagens como meios para a contemplação "daquele que observa". Esse sentido apresenta um pormenor na capa do livro do nono ano onde a figura do leitor se funde a do observador na foto. Aí é mobilizado um simulacro, conseguido pela tomada de ângulo da foto onde a mão nela inscrita sugere a própria mão do leitor a observar a paisagem através de um celular - aparelho bastante familiar aos estudantes, o que tem por finalidade realçar ainda mais o efeito de fusão. Em uma sociedade balizada pela pressa e por uma espécie de corrida do ouro pós-moderna - a corrida pela sobrevivência, para a maioria - a condição do viajante, que admira calmamente paisagens sem que nem mesmo um vulcão em erupção possa lhe causar afetação, tal qual vemos na capa do primeiro volume, representa o reconhecimento de um ícone que nos é familiar. Simbolicamente as imagens de capa, portanto, nos remetem ao explorador de mochila solitário descrito pelo logotipo da coleção ao lado do título do livro. Sua silhueta apresenta um homem que mira, de um aparelho no alto de uma elevação, uma paisagem distante. Essa distância dos exploradores nas capas também evidencia um distanciamento entre as pessoas no contexto do viajante solitário. Em nenhuma das paisagens de capa elas se fazem presentes, exceto na do livro do sétimo ano em que aparecem ao longe turistas no Pelourinho em Salvador/BA. É possível que se busque com isso fugir efetivamente às micronarrativas e às polêmicas apresentadas pela abordagem da Geografia Crítica quanto à paisagem (Figura 5).

Retomando a ideia das micronarrativas, ou no caso na falta delas, observa-se que nenhum explorador é negro, tampouco nenhum deles evidencia o corpo de uma mulher. Esse tipo de composição de imagem acaba por sutilmente reforçar macronarrativas que têm no homem branco europeu o legítimo "desbravador de territórios". Do ponto de vista da concepção de geografia, esse tipo de imagens destoa muito das capas dos livros de poucas décadas atrás em que a Geografia Crítica evidenciava as contradições no espaço geográfico por meio de imagens dos grupos à margem da sociedade capitalista. 
TIMMERS, J. C. M.; WEPPO, B. E.

Construindo sentidos nas leituras de imagens: um estudo sobre os livros didáticos de geografia

Figura 5 - Capa do livro do sétimo ano da coleção "Expedições Geográficas"

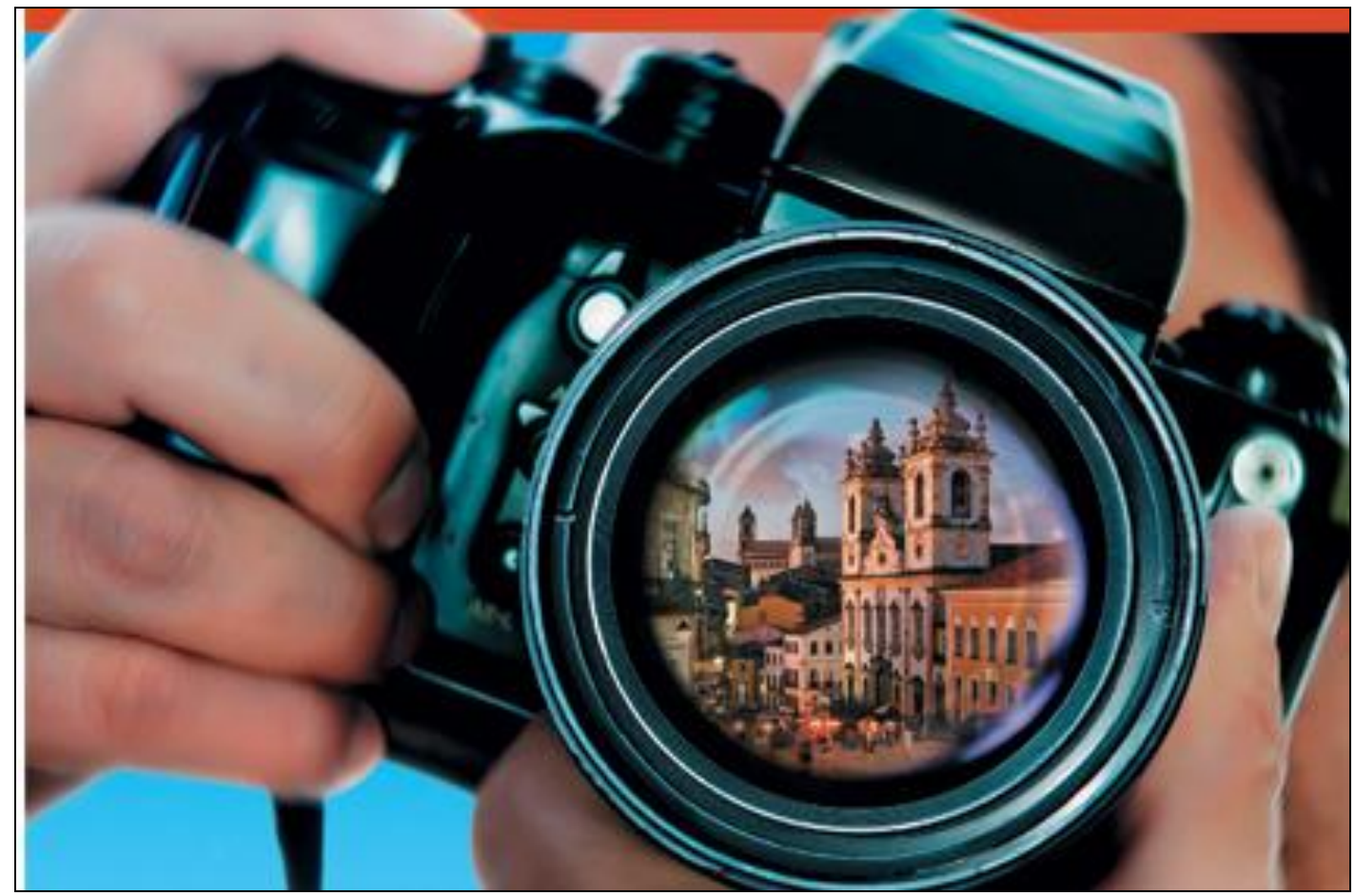

Nessa imagem da capa do livro do sétimo ano não há pessoas posando em um plano próximo da lente para compor a foto junto desse conjunto arquitetônico de Salvador/BA. O explorador figura isolado. O fundo azul também isola o fotógrafo dando a nítida ideia de uma foto montada. Fonte: Editora Moderna.

\section{CONSIDERAÇÕES FINAIS}

O objetivo principal desse texto que buscou aliar saberes da semiótica, educação e geografia era demostrar como o incremento na capacidade de leitura de imagens pode realçar o potencial de professores de Geografia e seus alunos para estabelecerem uma relação mais ponderada e menos passiva com os recursos visuais e seus sentidos, os quais se multiplicam no contexto técnico-informacional do espaço contemporâneo. Acredita-se que tenha se realizado aqui um exercício válido nesse sentido, embora tímido.

Ainda que em um contexto de ensino de geografia em que os livros didáticos se configuram como recurso de ensino, suas produções tornam-se melhores, sendo hoje bastante imagéticas, atrativas, e contemplando aspectos de uma sociedade plural e mais humana. Ainda assim é de suma importância que principalmente o professor saiba ler imagens para melhor educar visualmente, o que necessariamente inclui a promoção de olhares para geografias que pouco contemplamos. Professores de geografia munidos de instrumentos 
qualificados para análise de imagens têm mais condições de estimular seus alunos a desenvolverem olhares e aprendizagens mais ricos, aprofundados e diversos. Tais professores têm também mais habilidades para selecionar seus recursos de ensino, tendo mais condições de dialogar com os autores dos livros didáticos de modo a sugerir melhorias necessárias e questionar a carência de conteúdos que inclusive são demandados por legislação como é o caso da obrigatoriedade do ensino da cultura afro e indígena.

Por fim, a leitura das imagens de capa dos livros didáticos a partir da análise desenvolvida nesse artigo expôs como os autores desses livros podem se valer da influência de certas abordagens da geografia para criar sentidos que se vinculam ao conteúdo dos livros. A partir do exercício apresentado pôde se refletir sutilmente que tipos de olhares as capas não privilegiam na coleção em questão. Isso não desqualifica os livros analisados, os quais sempre se constituem por visões parciais da realidade. A temática proposta por essa coleção, de aprendizagem geográfica por meio de viagens, a qual é refletida sinteticamente nas capas dos livros, talvez represente mais um indício de virtualização da nossa experiência, o que apenas reforça a necessidade de discutir com os alunos os direcionamentos do olhar encaminhados por imagens encontradas nas capas dos livros didáticos de ampla distribuição nacional.

\section{REFERÊNCIAS}

ACASO, M. Classificación de terrores visuales. In: ___.Esto no sonlas Torres Gemelas: cómo apreender a leerlatelevisión y otrasimágenes. Madrid: Catarata, 2006. p.51-87.

ADAS, Melhem. ADAS, Sérgio. Expedições geográficas - 1 ed. - São Paulo: Moderna, 2011.

APPLE Inc. Manual del usuário delIphone para iOS 7. Disponível em <https://itunes.apple.com/us/book/manual-del-usuario-del-phone/id725663600?mt=11> Acessado em: dezembro de 2016.

BARBOSA, Ana Mae Tavares Bastos. A imagem no ensino da arte : anos mil novecentos e oitenta e novos tempos. 8. ed. São Paulo : Perspectiva, 2010. xxxiv, 149 p. : il.

BARTHES, Roland. O óbvio e o obtuso: ensaios críticos. Rio de Janeiro : Nova Fronteira, 1990c1982. 284 p. : il.

BRASIL. Lei 11.645 de 10 de março de 2008, relativa a obrigatoriedade do ensino da temática "História e Cultura Afro-Brasileira e Indígena". Disponível em <http://www.planalto.gov.br/ccivil_03/_Ato2011-2014/2014/Lei/L13010.htm> Acessado em: dezembro de 2016. 
COSTA, Marisa Cristina Vorraber. Estudos culturais, educação e pedagogia. In: Revista brasileira de educação. Belo Horizonte N. 23 (maio/ago. 2003), p. 36-61.

EDITORA MODERNA. Catálogo com a descrição da coleção "Expedições Geográficas". Disponível em:

<http://www.moderna.com.br/main.jsp?lumPageId=4028818B2E24D324012E3469E60A34A F\&itemId=8A7A83CB31BFE97401325EECE85B0548> Acessado em: dezembro de 2016.

GREIMAS, A. J. Por uma teoria do discurso poético. EM: [APOLLINAIRE, et ali] Essais de sémiotiquepoétique (Português) Ensaios de semiótica poética: São Paulo : Cultrix, 1975. P. 10-32.

HERNANDÉZ, Fernando. ?De qué hablamos cuando hablamos de cultura visual?. In: Educação \& realidade. Porto Alegre Vol. 30, n. 2 (jul./dez. 2005), p. 9-34.

LUCCI, Elian Alabi; BRANCO, Anselmo Lazaro. Geografia: Homem e espaço. Sétimo ano, São Paulo: $24^{\circ}$ Ed. Saraiva, 2015.

SENE, Eustáquio de. Entrevista com o prof. Dr. Sene, fotografias e(m) livros didáticos de Geografia.[Entrevistadores: OLIVEIRA JUNIOR, Wenceslao Machado de; SOARES, Elaine dos Santos], Revista Brasileira de Educação em Geografia. Campinas: v.3., n.6 (2013), p. 192-225.

RAUBER, Joaquim; TONINI, Ivaine M. Livro didático de geografia: pensando as aprendizagens. In: ENCONTRO DE PRÁTICAS DE ENSINO DE GEOGRAFIA DA REGIÃO SUL, 2., 2014, Florianópolis. Anais eletrônicos. Florianópolis:UFSC, 2014. Disponível em: <http://anaisenpegsul.paginas.ufsc.br> Acessado em junho de 2016.

SANTOS, Milton. A natureza do espaço: técnica e tempo, razão e emoção.4 ed. São Paulo: Editora da USP, 2012.

VESENTINI, Jose William. Brasil: sociedade e espaço. 14 Ed. São Paulo: Ática, 1991. .Para uma geografia crítica na escola. São Paulo : Ática, 1992. 135 p. 


\section{Autores}

Juliano da Costa Machado Timmers - Possui Graduação e Mestrado em Geografia pela Universidade Federal do Rio Grande do Sul (UFRGS). Atualmente é Doutorando em Geografia pela Universidade Federal do Rio Grande do Sul (UFRGS) e Professor na Secretaria Municipal de Educação de São Leopoldo (SMSP).

Branda Eloá Weppo - Possui Graduação em Design pela Universidade Luterana do Brasil (ULBRA). Especialização em Design Gráfico pela Universidade do Rio dos Sinos (Unisinos). Atualmente é mestranda em Educação pela Universidad de la Empresa (UDE) Montevidéu/Uruguai.

Artigo recebido em: 30 de março de 2017.

Artigo aceito em: 12 de junho de 2017. 